\title{
Bimbingan Karier dengan Teknik Modeling untuk Mengembangkan Kematangan Karier Peserta Didik
}

\author{
Shidratul Attika $\left.{ }^{1 *}\right)$ Juntika Nurihsan², Amin Budiamin ${ }^{3}$ \\ ${ }^{123}$ Universitas Pendidikan Indonesia \\ *) Correspondence Author, e-mail : shidratulattikaa@gmail.com
}

\begin{abstract}
Career maturity is the readiness of an individual in choosing their career. This research aimed to examine the effectiveness of career guidance with modeling techniques to develop the students' career maturity. This research implemented a quasiexperimental research with nonequivalent control group design. Career maturity questionnare was used as the research instrument. The participants consisted of nine experimental group students and nine control group students. The research samples were determined by implementing purposive sampling technique. Data analysis used the Independent Sample T-Test. The results of data analysis showed the $t$ value of $10.678>t$ table 1.746, then the career maturity of the experimental group students after given career guidance intervention with modeling techniques was higher than the control group students who were not given intervention. It can be concluded that career guidance with modeling techniques effective to develop students' career maturity.
\end{abstract}

Keywords: Career guidance; career maturity; modeling techniques

Article History: Received on 30/05/2020; Revised on 29/06/2020; Accepted on 06/07/2020; Published Online: 20/07/2020.

\section{Pendahuluan}

Setiap individu berkeinginan untuk memiliki taraf hidup yang baik, untuk itu individu perlu memiliki kesiapan karier, agar tidak salah memilih karier yang sesuai untuk memenuhi kelangsungan hidupnya. Karier yang dipilih seyogiayanya sesuai dengan minat dan potensi diri, sehingga tidak ada perasaan terbebani dalam melakukan tugas dan pekerjaannya nanti. Potensi yang dimiliki terus dikembangkan sehingga dapat direalisasikan menjadi hal yang dapat menunjang kesuksesan kariernya.

Karier a dalah serangkaian pekerjaan yang dijalani individu semasa hidupnya. Proses mengejar karier adalah salah satu tugas perkembangan yang penting di masa remaja yang berkaitan erat dengan kualitas hidup seseorang (Super; Erickson; dalam Rhee, et al., 2015). Arthur \& Lawrence (dalam Pratama \& Suharnan, 2014) mendefinisikan karier adalah serangkaian sikap, aktivitas, atau perilaku yang diasosiasikan dengan peran sepanjang kehidupan seseorang. Dillard (1985) membedakan antara pekerjaan (job) dengan karier (career), di mana job mengacu pada pekerjaan yang tidak berlanjut dan mungkin bersifat sementara, sedangkan karier mengimplikasikan adanya latihan dan komitmen, yang merupakan jalan kehidupan kerja yang dipilih individu. 
Peserta didik jenjang SMA seyogiayanya sudah mulai mempersiapkan karier yang akan dipilih. Individu yang berada di tingkat SMA tergolong dalam kategori usia remaja, di mana masa remaja sangat kompleks sehingga memerlukan bantuan dan bimbingan yang lebih komprehensif (Yusuf, 2010). Untuk itu perlunya bimbingan karier, sebagai upaya pemberian bantuan agar individu dapat mengenal dan memahami dirinya, mengenal dunia kerjanya, mengembangkan masa depannya sesuai dengan bentuk kehidupan yang diharapkan, serta dapat mengambil keputusan secara tepat dan bertanggungjawab atas keputusan yang diambilnya sehingga mereka mampu mewujudkan dirinya secara bermakna (Yusuf \& Nurihsan, 2016).

Kesiapan terhadap pemilihan karier disebut dengan kematangan karier. Super (dalam Atli, 2016) mendefinisikan konsep kematangan karier sebagai kesiapan untuk membuat rencana tentang membuat pilihan karier, memiliki kesadaran tentang karier, dan mengambil tanggung jawab untuk membuat pilihan karier. Ketika peserta didik membuat pilihan karier sendiri, baik pendidikan maupun pekerjaan, dipengaruhi oleh berbagai faktor lingkungan seperti status sosial ekonomi keluarga dan faktor psikologis seperti ciri-ciri dan motif kepribadian (Naidoo, dalam Kim \& Oh, 2013). Kematangan karier, sebagaimana dijelaskan oleh Crites (dalam Heo \& Kim, 2016) mengacu pada kemampuan seseorang untuk memilih karier secara selaras dan terarah untuk pekerjaan di masa depan. Kematangan karier adalah sejauh mana seseorang memiliki minat terhadap kariernya di masa depan, memiliki kesiapan untuk karier, dan terlibat dalam perkembangan karier selama rentang hidupnya.

Aspek kematangan karier menurut Super (dalam Sharf, 2010) meliputi: (1) perencanaan karier; pentingnya perencanaan karier agar peserta didik memiliki gambaran tentang kariernya di masa depan; (2) eksplorasi karier; bertujuan agar peserta didik mulai menjelajahi dan mencari informasi-informasi karier berdasarkan sumber informasi yang terbaru dan terpercaya; (3) pengambilan keputusan karier; peserta didik secara matang dapat mengambil keputusan karier sesuai dengan pemikiran dan pengetahuannya mengenai karier yang diinginkan; (4) informasi dunia kerja; informasi mengenai dunia kerja perlu diketahui sejak dini agar peserta didik memiliki gambaran mengenai persyaratan dalam memasuki dunia kerja, informasi penghasilan yang didapatkan, serta kiat-kiat memperoleh kesuksesan dalam berkarier; (5) pengetahuan tentang kumpulan pekerjaan yang diminati; agar individu mengetahui tentang tugas dari kelompok-kelompok pekerjaan, serta agar peserta didik memahami alasan yang tepat memilih pekerjaan tersebut, dan (6) realisasi keputusan karier, agar peserta didik dapat menyesuaikan antara kemampuan dan pilihan pekerjaannya secara realistis.

Peserta didik SMA seyogiayanya memiliki pemahaman karier yang baik. Namun pada kenyataannya di lapangan terdapat permasalahan karier yang beragam. Salah satunya hasil studi yang dilakukan oleh Budiamin (2002) di Kabupaten Bandung yaitu sebanyak $90 \%$ siswa menyatakan masih bingung dalam memilih karier (studi lanjut) di masa depan dan $70 \%$ siswa menyatakan rencana masa depan tergantung pada orang tua. Selanjutnya studi yang dilakukan oleh Yulianti (2015) menyebutkan bahwa permasalahan karier yang dialami oleh siswa SMAN 1 Kota Tasikmalaya adalah kesulitan dalam memilih program studi ke sekolah lanjutan dan pekerjaan apa yang cocok dan sesuai 
dengan potensi dan kemampuan siswa. Kendala yang dapat dilihat seperti siswa mengalami keraguan dalam memilih jurusan, adanya perbedaan keinginan antara orang tua dan siswa, dan juga siswa merasa takut menentukan pilihan karena tidak sesuai dengan kemampuan akademik dan ekonomi keluarganya.

Salah satu upaya untuk mengembangkan kematangan karier peserta didik adalah dengan menggunakan teknik modeling, di mana peserta didik dapat mempelajari suatu perilaku positif yang baru dari hasil pengamatan terhadap objek yang dijadikannya sebagai model. Teknik modeling dikembangkan oleh Albert Bandura yang merupakan salah satu komponen teori belajar sosial Bandura. Modeling merupakan istilah yang menunjukkan adanya proses belajar melalui observasi atau pengamatan terhadap individu lain, dan terjadi perubahan akibat dari adanya peniruan melalui pengamatan yang telah dilakukan. Modeling adalah konsekuensi dari perilaku meniru individu lain berdasarkan pengalaman langsung ataupun tidak langsung, sehingga reaksi emosional dan rasa takut seseorang dapat dihapuskan (Bandura, dalam Erford, 2016).

Peserta didik mendapatkan perilaku yang lebih efektif dengan mengamati secara langsung objek/ individu yang dijadikan model. Melakukan pengamatan dan imitasi terhadap tokoh yang sukses adalah hal yang dapat dilakukan peserta didik sehubungan dengan tugas perkembangan karier remaja. Kognitif remaja telah sampai pada tahap perkembangan untuk dapat berpikir secara abstrak dan logis, sehingga mampu membuat sebuah kesimpulan (Korohama, et al, 2017). Nursalim (2005) memaparkan bahwa modeling merupakan proses perubahan yang terjadi pada diri individu namun tidak sama persis dengan apa yang dilakukan model melainkan individu akan mengembangkan perilaku baru sebagai modifikasi hasil kognitif dari perilaku model yang dilihat.

Adapun faktor seseorang belajar dari seorang model menurut Feist \& Gregory (2010) yaitu: (1) karakteristik model menjadi hal dasar yang diperhatikan individu dalam memilih seseorang yang akan menjadi model untuk diamati. Individu akan cenderung mengikuti model yang lebih kompeten untuk proses belajar membentuk perilaku yang positif; (2) individu yang merasa perlu meningkatkan kemampuan, motivasi, atau kekuatan lebih mungkin melakukan modeling untuk mengembangkan diri; (3) konsekuensi dari tindakan yang dimunculkan oleh model yang diobservasi akan membuat individu belajar meniru dengan berbagai modifikasi dari hasil kognitifnya atau melakukan hal yang berbeda dari tindakan model.

Dalam penelitian ini menggunakan teknik modeling live model dan symbolic model, dimana live model adalah model yang dapat diamati secara langsung, karena merupakan orang terdekat dari peserta didik, seperti orang tua, keluarga, kerabat yang sukses, atau guru. Sedangkan symbolic model adalah model berupa video kisah orangorang sukses yang memiliki kontribusi terhadap perkembangan dunia. Modeling mengajarkan berbagai macam keterampilan kepada peserta didik. Secara umum live modeling lebih efektif dalam mengajarkan keterampilan personal dan sosial, sementara symbolic model membantu untuk mengatasi masalah kognitif (Erford, 2016).

Kematangan karier penting agar peserta didik tidak salah memilih jalan hidup ke depan. Keraguan yang terlihat dari peserta didik ketika ditanya mengenai masa 
depannya menjadi salah satu gejala yang tampak dari masih kurangnya kematangan karier peserta didik. Dalam memilih karier, tidak dianjurkan untuk memilih karier hanya sekedar ikut-ikutan teman, atau karena gengsi kalangan remaja. Karier yang dipilih haruslah sesuai dengan potensi, minat dan kemampuan yang dimiliki oleh peserta didik. Berdasarkan latar belakang mengenai pentingnya peserta didik untuk mempersiapkan kariernya di masa depan, maka penting untuk mengembangkan kematangan karier siswa melalui layanan bimbingan karier dengan teknik modeling.

Hipotesis dalam penelitian ini adalah "Bimbingan karier dengan teknik modeling efektif untuk mengembangkan kematangan karier peserta didik". Penelitian ini bertujuan untuk menguji efektivitas bimbingan karier dengan teknik modeling untuk mengembangkan kematangan karier peserta didik kelas X SMA Negeri 6 Bandung. Penelitian ini diharapkan dapat memberikan sumbangan terhadap perkembangan ilmu pengetahuan dan memperkaya khazanah teori mengenai bimbingan karier dengan teknik modeling untuk mengembangkan kematangan karier peserta didik. Secara praktis, bimbingan karier dengan teknik modeling dapat direkomendasikan kepada guru bimbingan dan konseling untuk memanfaatkan hasil penelitian guna menambah pengetahuan dan keterampilan dalam memberikan bantuan terhadap peserta didik melalui bimbingan karier dengan teknik modeling. Bagi peneliti selanjutnya dapat dijadikan referensi pengembangan bimbingan maupun konseling karier terutama dalam bidang kematangan karier.

\section{METODE}

Metode penelitian yang digunakan adalah eksperimen kuasi. Eksperimen kuasi (Cresswell, 2015) merupakan penelitian yang membandingkan dua kelompok sasaran penelitian, di mana satu kelompok diberikan perlakuan (eksperimen) dan kelompok lainnya dikendalikan pada suatu keadaan (kontrol) sebagai pembanding. Kelompok kontrol tidak diikutsertakan dalam bimbingan karier dengan teknik modeling dengan pertimbangan bahwa kelompok kontrol dapat mengembangkan kematangan karier dari sumber lain dan mewakili kondisi normal subjek yang tidak diberi intervensi (Heppner, et al, 2008).

Desain penelitian yang digunakan adalah nonequivalent control group, yang membagi partisipan menjadi dua kelompok yaitu kelompok eksperimen dan kelompok kontrol. Peserta didik kelas X SMA Negeri 6 Bandung yang memiliki skor kematangan karier rendah diberikan pre-test dan post-test dengan menggunakan instrumen kematangan karier. Dalam penelitian ini hanya kelompok eksperimen yang diberi perlakuan bimbingan karier dengan teknik modeling, sementara kelompok kontrol tidak mendapat perlakuan. Analisis efektivitas bimbingan karier dengan teknik modeling untuk mengembangkan kematangan karier peserta didik akan dilakukan dengan menggunakan uji $\mathrm{t}$.

\section{Populasi dan Sampel Penelitian}

Populasi dalam penelitian ini adalah seluruh peserta didik kelas X SMAN 6 Bandung dan sampel penelitian ini adalah sebagian peserta didik kelas X SMAN 6 Bandung. Pemilihan 
peserta didik kelas $\mathrm{X}$ karena individu yang berusia 15 - 24 tahun masuk pada tahap eksplorasi, di mana individu mulai mencari berbagai alternatif karier, dan menentukan tujuan karier sementara tapi dapat diandalkan. Dalam tahap eksplorasi individu mulai mencoba menggali potensi diri dan mengeksplor berbagai pekerjaan (Super, dalam Suherman, 2013)

Selanjutnya ditentukan sampel penelitian yang merupakan bagian dari populasi. Teknik sampling yang digunakan adalah purposive sampling. Teknik purposive sampling digunakan untuk mengurangi ancaman terhadap validitas internal pada metode penelitian eksperimen kuasi (Creswell, 2015). Sampel dipilih dari peserta didik yang memiliki tingkat kematangan karier yang rendah. Adapun banyaknya sampel pada penelitian ini adalah 18 orang yang memiliki capaian kematangan karier terrendah dan dibagi menjadi sembilan peserta didik kelompok eksperimen dan sembilan peserta didik kelompok kontrol.

Instrumen yang digunakan adalah instrumen kematangan karier yang disusun berdasarkan kisi-kisi yang telah dibuat dalam item pernyataan positif dan negatif. Setiap item terdapat lima alternatif jawaban yakni sangat sesuai (SS), sesuai (S), kurang sesuai (KS), tidak sesuai (TS) dan sangat tidak sesuai (STS). Dalam metode ini, peserta didik diminta untuk memilih salah satu dari lima alternatif jawaban yang lebih menggambarkan keadaan dirinya. Kisi-kisi instrumen untuk mengukur kematangan karier peserta didik dikembangkan dari definisi operasional variabel penelitian.

\section{HASIL DAN PEMBAHASAN}

Hasil perhitungan data empiris skor pre-test dan post-test kematangan karier pada kelompok eksperimen dan kontrol dapat dilihat pada tabel berikut.

Tabel 1. Hasil Perhitungan Persentase Capaian Pre-test dan Post-test Kematangan Karier Kelompok Eksperimen dan Kelompok Kontrol

\begin{tabular}{|c|c|c|c|c|c|c|}
\hline \multirow[t]{2}{*}{ Kelompok } & \multicolumn{4}{|c|}{ Persentase } & \multirow[t]{2}{*}{ Gain } & \multirow[t]{2}{*}{ Ket } \\
\hline & Pre-test & Ket & Post-test & Ket & & \\
\hline Eksperimen & $43,37 \%$ & Rendah & $62,34 \%$ & Sedang & $18,97 \%$ & Meningkat \\
\hline Kontrol & $44,66 \%$ & Rendah & $42,20 \%$ & Rendah & $-2,46 \%$ & Menurun \\
\hline
\end{tabular}

Tabel 1 menunjukkan bahwa kelompok eksperimen mengalami peningkatan persentase kematangan karier, sementara kelompok kontrol mengalami penurunan. Perubahan skor kematangan karier pada masing-masing responden kelompok eksperimen sebelum dan setelah diberikan intervensi dapat dilihat pada tabel berikut. 
Tabel 2. Perubahan Kematangan Karier Peserta Didik Kelompok Eksperimen

\begin{tabular}{ccccc}
\hline No Resp. & \multicolumn{2}{c}{ Kematangan Karier } & Gain & Ket \\
Pre-test & Post-test & & \\
R02 & 70 & 119 & 49 & Meningkat \\
R23 & 71 & 110 & 39 & Meningkat \\
R58 & 76 & 107 & 31 & Meningkat \\
R121 & 72 & 107 & 35 & Meningkat \\
R133 & 70 & 100 & 30 & Meningkat \\
R143 & 76 & 104 & 28 & Meningkat \\
R155 & 75 & 101 & 26 & Meningkat \\
R188 & 76 & 108 & 32 & Meningkat \\
R194 & 78 & 98 & 20 & Meningkat \\
\hline
\end{tabular}

Berdasarkan skor antara sebelum dan setelah dilakukan intervensi pada tabel 2 menunjukkan bahwa skor setiap anggota kelompok eksperimen meningkat dari kategori rendah menjadi kategori sedang. Hal ini menunjukkan bahwa intervensi bimbingan karier dengan teknik modeling memiliki pengaruh terhadap perubahan kematangan karier pada kelompok eksperimen. Adapun peningkatan yang terjadi dapat dilihat pada gambar berikut.

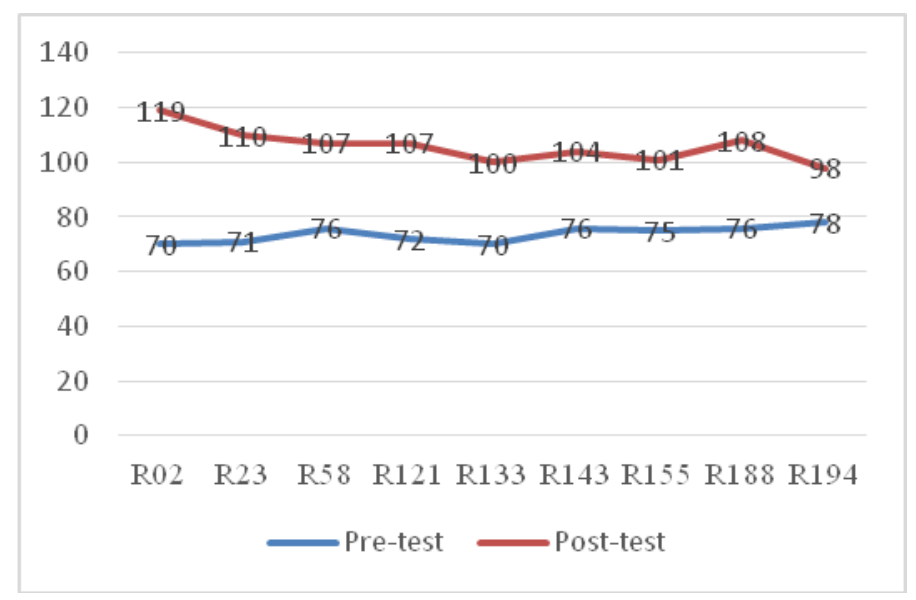

Gambar 1. Peningkatan Rata-rata Kematangan Karier Peserta Didik Kelompok Eksperimen

Uji Perbedaan Rata-rata Hasil Post-test Kelompok Eksperimen dan Kelompok Kontrol Setelah diberikan treatment berupa bimbingan karier dengan teknik modeling pada kelompok eksperimen, dilakukan uji perbedaan rata-rata skor post-test antara kelompok eksperimen dan kelompok kontrol dengan menggunakan uji Independent Sample T-Test dengan bantuan software SPSS 20. 
Setelah dilakukan pengujian menggunakan SPSS 20 diperoleh data yang ditunjukkan pada tabel 3 berikut:

Tabel 3. Hasil Uji Statistik Kelompok Eksperimen dan Kelompok Kontrol Setelah diberi Perlakuan

\begin{tabular}{llcclll}
\hline & & \multicolumn{3}{c}{ Group Statistics } & & \\
& Kelompok & N & Mean & $\begin{array}{l}\text { Std. } \\
\text { Deviation }\end{array}$ & $\begin{array}{l}\text { Std. } \\
\text { Mean }\end{array}$ Error \\
Kematangan & Eksperimen & 9 & 106,00 & 6,325 & 2,108 & \\
Karier & Kontrol & 9 & 71,78 & 7,242 & 2,414 & \\
\hline
\end{tabular}

Berdasarkan tabel 3 diketahui bahwa rata-rata kedua kelompok sebelum diberi perlakuan menunjukkan adanya perbedaan. Dengan demikian secara deskriptif statistik dapat disimpulkan ada perbedaan rata-rata skor kematangan karier antara kelompok eksperimen dan kelompok kontrol setelah diberi intervensi bimbingan karier dengan teknik modeling. Selanjutnya untuk membuktikan apakah perbedaan tersebut berarti signifikan (nyata) atau tidak ditafsirkan dalam output independent sample test berikut ini.

Tabel 4. Hasil Uji Independent Sample T-test Terhadap Hasil Posttest Kelompok Eksperimen dan Kelompok Kontrol

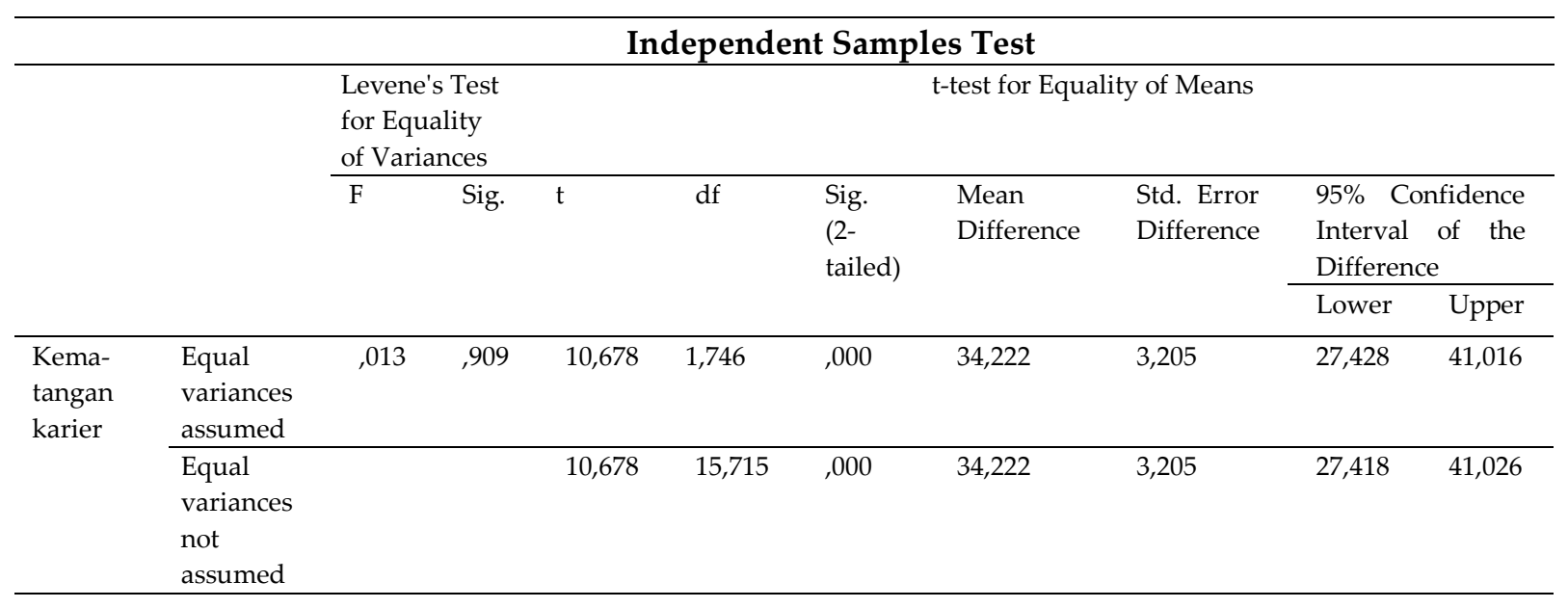

Berdasarkan tabel 4 diperoleh nilai $\mathrm{t}$ hitung sebesar 10,678 dan $\mathrm{t}$ tabel dengan $\mathrm{df}$ (degree of freedom) 16 pada taraf signifikan 5\% sebesar 1,746 $(10,678>1,746)$ yang artinya kematangan karier kelompok eksperimen setelah diberi intervensi bimbingan karier dengan teknik modeling lebih tinggi daripada kelompok kontrol. Berdasarkan hasil perhitungan menunjukkan bahwa terdapat perbedaan capaian kematangan karier kelompok eksperimen setelah diberikan intervensi bimbingan karier dengan teknik modeling dengan peserta didik yang tidak mengikuti bimbingan karier dengan teknik modeling (kelompok kontrol). Sehingga dapat disimpulkan bimbingan karier dengan teknik modeling efektif untuk mengembangkan kematangan karier peserta didik kelas $\mathrm{X}$ SMA Negeri 6 Bandung. 
Dalam teori konstruksi karier (Savickas, dalam Savickas \& Porfeli, 2011) menyatakan bahwa siswa harus menjalankan tugas-tugas pilihan karier karena peduli akan masa depan mereka, rasa ingin tahu untuk mencoba mengeksplorasi peluang sosial, dan keyakinan untuk terlibat dalam merencanakan pekerjaan di masa depan dan berusaha untuk menjadikannya nyata. Kepedulian terhadap karier berarti merasa penting untuk mempersiapkan karier masa depan, sehingga individu memiliki kesadaran akan tugas perkembangan karier dan pilihan karier yang akan dibuat.

Sebuah studi yang dilakukan oleh Răduleț (dalam Crisan, et al, 2015) bertujuan untuk melihat bagaimana cara siswa membuat keputusan karier. Dari data yang diidentifikasi ditemukan bahwa siswa bingung dalam mengenal kariernya sehingga dibutuhkan bimbingan karier yang akan membantu siswa dalam proses klarifikasi minat, kemampuan, dan keterampilan agar mereka memahami faktor yang berperan dalam perencanaan karier dan mempengaruhi keputusan karier mereka. Asesmen kebutuhan konseling harus selalu proaktif, agar kesenjangan antara keadaan sekarang dan keadaan yang diinginkan mendapatkan solusi yang optimal.

Penelitian yang dilakukan Korohama, et al (2017) pada siswa SMK Negeri 2 Kota Kupang menunjukkan bahwa bimbingan kelompok dengan teknik modeling efektif dalam meningkatkan kematangan karier siswa. Pada setting kelompok, bimbingan karier efektif karena terdapat interaksi langsung antara anggota kelompok, pemimpin kelompok dan fasilitator. Modeling yang dilakukan dengan menghadirkan langsung model atau melalui media video, dapat membantu siswa mengamati langsung dan belajar dari model tersebut mengenai ilmu bagi siswa untuk memutuskan kariernya.

Penelitian tentang kematangan karier yang dilakukan oleh Pratama \& Suharnan (2014) menunjukkan bahwa adanya hubungan antara konsep diri dan internal locus of control dengan kematangan karier siswa SMA. Locus of control menggambarkan sejauh mana individu memandang hubungan antara perbuatan yang dilakukan dengan akibatnya. Jika dikaitkan dengan pemilihan karier, dapat diartikan seberapa jauh individu memberdayakan potensi dirinya agar dapat memperoleh hasil terbaik dalam proses kematangan karier seseorang. Siswa SMA yang memiliki internal locus of control, ketika dihadapkan dengan kematangan karier, maka akan melakukan usaha untuk mengenali diri, mencari tahu tentang pekerjaan dan langkah-langkah pendidikan serta berusaha mengatasi masalah yang berkaitan dengan pemilihan karier. Sehingga dapat disimpulkan bahwa semakin tinggi konsep diri dan internal locus of control siswa maka semakin tinggi juga kematangan karier pada siswa.

Temuan penelitian oleh Adiputra (2015) pada siswa kelas X SMA Yasmida Ambarawa menunjukkan bahwa intervensi bimbingan karier dengan teknik modeling dapat meningkatkan salah satu aspek dari kematangan karier, yaitu aspek perencanaan karier. Intervensi yang dilakukan menggunakan pendekatan behavior, yang diperkirakan tepat untuk mengembangkan arah perencanaan karier siswa. Selanjutnya penelitian yang dilakukan oleh Bae (2017) terhadap individu usia remaja akhir sampai pertengahan umur 20an menunjukkan bahwa kematangan karier meningkat seiring berjalannya waktu. Tingkat kematangan karier siswa dapat dipengaruhi oleh beberapa faktor, salah satunya 
adalah tingkat ekonomi keluarga, gender, pengalaman dalam melakukan konseling karier, dan prestasi akademik.

Berdasarkan beberapa temuan penelitian yang telah dipaparkan dapat disimpulkan bahwa kematangan karier peserta didik dapat dikembangkan agar peserta didik memiliki kesiapan dalam memilih dan mengambil keputusan kariernya. Upaya untuk mengembangkan kematangan karier atau aspek kematangan karier dapat berupa pemberian bimbingan karier, konseling karier, dengan menggunakan teknik modeling atau teknik lainnya. Faktor internal dan eksternal juga mempengaruhi tingkat kematangan karier seseorang, seperti faktor prestasi, motivasi orang tua, gender, bahkan keadaan ekonomi keluarga juga mempengaruhi perkembangan karier seseorang. Pentingnya kematangan karier bagi setiap peserta didik, sehingga perlu diberikan layanan bimbingan karier agar peserta didik memiliki gambaran mengenai karier dan mampu membuat keputusan karier nantinya.

Pada penelitian ini, setiap sesi bimbingan karier dengan teknik modeling bertujuan untuk mengembangkan aspek kematangan karier peserta didik. Perubahan tidak hanya diukur dan dilihat secara statistik saja, namun ditambah dengan pengamatan yang bersifat kualitatif yang menandai adanya sebuah perubahan pada kelompok eksperimen. Perubahan tersebut dianalisis berdasarkan jurnal kegiatan sehingga secara praktis dapat dilihat bahwa bimbingan karier dengan teknik modeling efektif untuk mengembangkan kematangan karier peserta didik. Disetiap akhir sesi intervensi juga dilakukan refleksi yang bertujuan untuk mengetahui sejauh mana perkembangan peserta didik setelah diberi intervensi.

\section{KESIMPULAN}

Bimbingan karier dengan teknik modeling efektif dalam mengembangkan kematangan karier peserta didik kelompok eksperimen. Hal ini dilihat dari skor pre-test yang meningkat pada saat post-test setelah dilakukan intervensi, juga terjadi peningkatan skor dari kategori rendah kematangan kariernya menjadi kategori sedang. Keefektifan juga dapat dilihat dari hasil uji t. Berdasarkan pengamatan peneliti peserta didik memiliki antusiasme yang baik pada saat diberikan layanan bimbingan karier disetiap sesinya. Adapun saran bagi penelitian selanjutnya yaitu: (1) intervensi bimbingan karier dengan teknik modeling tidak hanya diberikan kepada kelompok eksperimen, namun kelompok kontrol juga dapat diberi bimbingan karier dengan teknik lainnya sebagai perbandingan; (2) melibatkan secara langsung tokoh-tokoh sukses untuk menjadi live model.

\section{REFERENSI}

Adiputra, S. (2015). Penggunaan Teknik Modeling Terhadap Perencanaan Karier Siswa. Jurnal Fokus Konseling 1 (1), 45-56.

Atli, A. (2016). The Effects of Trait-Factor Theory Based Career Counseling Sessions on the Levels of Career Maturity and Indecision of High School Students. Universal Journal of Educational Research 4(8), 1837-1847. https://doi.org/10.13189/ujer.2016.040813 
Bae, S.M. (2017). An Analysis of Career Maturity Among Korean Youths Using Latent Growth Modeling. School Psychology International, 1-16. https://doi.org/10.1177/0143034317709527

Budiamin, A. (2002). Manajemen Bimbingan Karier pada SMU Negeri di Kabupaten Bandung. Jurnal Psikologi Pendidikan dan Bimbingan 2, 259-266.

Creswell, J. W. (2015). Research Design; Pendekatan Metode Kualitatif, Kuantitatif dan Campuran (Penerjemah Ahmad Fawaid dan Rianayati). Yogyakarta; Pustaka Pelajar.

Crişan, C., Pavelea, A., Ghimbuluț, O. (2015). A Need Assessment on Students' Career Guidance.Procedia - Social Behavioral Sciences 180, 1022-1029. https://doi.org/10.1016/j.sbspro.2015.02.196

Dillard, J.M. (1985). Life Long Career Planning. Ohio: A Bell \& Howell Company Colombus.

Erford, B.T. (2016). 40 Teknik yang Harus diketahui Setiap Konselor. Yogyakarta: Pustaka Pelajar.

Feist, J. \& Gregory J.F. (2010). Teori Kepribadian (Penerjemah Hendrianto). Jakarta: Salemba Humanika.

Heo, G,. \& Kim, T,. (2016). Autoregressive Cross-Lagged Modeling of the Reciprocal Longitudinal Relationship Between Self-Esteem and Career Maturity. Journal of Career Development 43(3), 273-288. https://doi.org/10.1177/0894845315598002

Heppner, et al. (2008). Research Design in Counseling (third edition). USA: Thomson Higher Education.

Kim, K.N.\& Oh, S.H. (2013). Effects of Social Constraints on Career Maturity: The Mediating Effect of the Time Perspective. Asia Pasific Education 14, 221-229. https://doi.org/10.1007/s12564-013-9240-6

Korohama, K.E.P., et al (2017). Model Bimbingan Kelompok dengan Teknik Modeling untuk Meningkatkan Kematangan Karier Siswa. Jurnal Bimbingan dan Konseling 6(1), 68 - 76.

Nursalim, M. (2005). Strategi Konseling. Surabaya: UNESA University Press.

Pratama, B.D. \& Suharnan. (2014). Hubungan antara Konsep Diri dan Internal Locus of Control dengan Kematangan Karier Siswa SMA. Persona, Jurnal Psikologi Indonesia 3(3), hlm. 213-222.

Rhee, E., et al. (2015). The Relationship Among the Six Vocational Identity Statuses and Five Parent Dimensions of Planned Happenstance Career Skills. Journal of Career Development, 1-11. https://doi.org/10.1177/0894845315602120

Savickas, M. \& Porfeli, E.J. (2011). Revision of the Career Maturity Inventory :The Adaptability Form. Journal of Career Assessment 19(4), 355 - 374. https://doi.org/10.1177/1069072711409342

Sharf, R. (2010). Applying Career Development Theory of Counseling. USA: Cengage Learning.

Suherman, U. (2013). Bimbingan dan Konseling Karier; Sepanjang Rentang Kehidupan. Bandung: Rizqi Press.

Yulianti. W. (2015). Intervensi Layanan Bimbingan Karier Untuk Peningkatan Kematangan Karier (Penelitian Kuasi Eksperimen Terhadap Siswa XI SMAN 1 
Tasikmalaya Tahun Ajaran 2014/2015). (Unpublish master's thesis). Universitas Pendidikan Indonesia, Bandung, Indonesia.

Yusuf, S. (2010). Psikologi Perkembangan Anak \& Remaja. Bandung: PT Remaja Rosdakarya.

Yusuf, S. \& Nurihsan, J. (2016). Landasan Bimbingan dan Konseling. Bandung: PT. Remaja Rosdakarya. 